\title{
Empowerment Administrative Court Towards Future Court in Global Governance
}

\author{
Aju Putrijanti \\ \{aputriyanti@yahoo.com\} \\ Faculty of Law, Diponegoro University, Semarang, Indonesia
}

\begin{abstract}
The dynamic development happens in a few years and gives impact to administrative law. Globalization makes everything able to access, such as borderless information technology, politic, economy, and social life. Due to this matter, administrative law becomes global and impact on local governance. This condition has to be followed by governance and judiciary system. Act No 30 the Year 2104 of Governance Administration regulates all the duty of government's action also as material law to Act No five the Year 1986 of Administrative Court and its amendments. The Administrative Court's authority has become widely by accepting the application as well as a lawsuit. The issue is how to empower the Court as responding to global governance. Some principles should be strictly implemented and understood that the State has to adapt on their own. The Court has to implement supervision for governance in the judiciary system as law enforcement. The method is using normative and comparative approach adjust with legal principles. To fulfill the needs in global governance, the Administrative Court has to evolve with the changes. The contribution is to empower the role of the Court in the new paradigm of global governance. The regulations should be harmonized, so there will be the uncertainty of law conditions. Administrative Court has to follow the globalization in modern administrative law.
\end{abstract}

Keywords: empowerment, an administrative court, global governance.

\section{Introduction}

In the welfare state, the role of government is broader by arranging public health, education, housing, public services, and related matters. It is essential to have proper, transparent regulations of government's duty, whether private or public sector. In this globalization era, the fast-changing of information technology have an impact on our social life, similarly the regulations.

The modernization will brings globalization as it happens, and should be followed with the right law. Law No 30 / 2014 of Governance Administrative is new administrative law to guide the government's duty, and it also as material law to Administrative Court. The shifting role of government in the 20th century, definitely demand the more role of government and it should be regulated with appropriate laws. Moreover, the government's actions should be regulated precisely, and people should get their rights to fulfill correctly.

The Administrative Court is one of the judiciary body under The Supreme Court with specific competence based on Law No 5/ 1986 of Administrative Court and its amendments. The Administrative Court aims to stabilized the rights of the citizen and the duty of Government, to protect the civil rights, the law enforcement of administrative law. This covers a wide range of government's duty, so it has to regulates based on the above 
aims.

To deal with the massive changing in various sector, the government should prepare the regulations, law enforcement, government reform, and judiciary system. Supervision of government's act whether public or private law is strongly needed. It is the role of the Administrative Court to make the supervision. The problem is how to empower the Administrative Court in global governance, consider the massive change.

\section{Methodology}

The problem is analyzed using normative and comparative approach. Normative approach is using by analyzing the primarily material such as regulations, judge's decree, and secondary material are journals, books as references. (1) A comparative approach is using to know about the development of administrative court in other countries due to the globalization.

\section{Findings}

\subsection{The Administrative Court}

The relationship between government and citizenship are developed from time to time. Also, the role of government in regulating citizenship, the duties of citizenship are become vary; it is a part of the welfare state. The development of the relationship will influence the kind of duties and rights for both parties. Ten Berge in his research divided 2 two) typology of duty, the passive duty, and active duty. (2) Inactive duties to inform the government authorities and civil servants and to cooperate with them as part of modern governance for today. The civilization has rights to get any information from government, and government must give information based on regulations; this is transparency as an essential principle of good governance. He also gave general limitations to create duties; it has to be necessary and serve a reasonable object, has to be proportional compared to planned objectivity and citizen must able to adhere the duty, the creation of duty must comply with the requirements of the rule of law. These are standard regulations to build good governance without ignoring the requirements of the rule of law, and also needs a judicial supervisor to control the government duties.

The concept of Administrative Court introduced by F.J. Stahl in the civil law system, which is different from the universal law system as they did not admit the court at the beginning (3). In-Law No 5 / 1986 of Administrative Court the object is government's decree which has legal consequences to individu or a private company, should be individual, final, concrete ( vide Article 1 number 3). In the beginning, the lawsuit more to cancellation of permission, government's staffing, cancellation of landowners certificate is dominant. After reformation era, the existence of Administrative Court is increase, as there are vary of dispute, i.e dispute of election of regional head, environment disputes, decree of mining permission, auction, taxes, etc. (4) This conditions arise because the civilization starts to realize their citizen's right, on the other side is a control to governance body or officer to do their duties based on law. In modern governance, the control of their duty is essential; this is to minimize the abuse of power and brings the democratic system properly.

The existing Administrative Court has more cases due to the above reasons. People started to realize their citizen's rights, the relationship with the governance, it brought a new paradigm of Administrative Court in law enforcement of administrative law. The 
administrative law has also increased for some years, followed the globalization and fastchanging in politics, economy, social life, etc.

Indonesia did not have an administrative law in writing, which should be as a base for governance body and official to implement their duties. The Law, No 30/2014 of Governance Administration, had been legalized for three years, this was a new paradigm for both administrative law and administrative court. Now the government has regulations to do their duties based on mandate, delegation, besides there is a ban of abuse of power, the administrative sanctions and many other regulations which is essential. The paradigm has been changed it means that the role of governance become vary, but on the other side there is also some restraint of activity, the administrative court has a new paradigm too and should adjust with the new regulation.

The Law, No 30 /2014 of Governance Administration, was very much awaited because it is necessary regulations with 2 (two) important points, first as a legal basis for governance to implement their duties correctly, second as material law against The Administrative Court. Before it was legalized, it was difficult to found the legal basis and material law to Administrative Court; mostly, it was referred to concepts, theories of administrative law, customary law in governing the governance. This is a difficult time for The Administrative Court, so does the governance and the development of administrative law in Indonesia.

The authority of Administrative Court become wider after the Law No 30 / 2014 of Governance Administration had been legalized as material law to Administrative Court (from now on will be named as Law of Governance Administration). The Law of Governance Administration regulates the government's act in the public sector, the administration sanction, the abuse of power, the principle of good governance and related things to governance administration. This introduced the electronic decree which has not been known before; this came out because of the needs of global governance.

To envisage the global governance, Administrative Court has to finalized their own problems beside to manage the court administration in general. The legal obedience of Plaintiff to implement the judge's verdict is weak. This is very important in the globalization era since the trust of people is highly dependent on the legal obedience of Plaintiff (5). Refer to the system of law by Lawrence Friedman, legal obedience is a legal culture, and it depends on the responsibility of everyone.

\subsection{Globalization of governance.}

The meaning of globalization as stated by Giddens ' globalization is about the intensification of worldwide social relations which link distant localities in such a way that local happenings are shaped by events many occurring miles away and vice versa'(6). Government has to follow the globalization as it happens very quickly and the regulations have to adjust with international law, become borderless in many sectors.

The government's actions in the private and public sector should be based on the development happens by considers the Constitution. The development of government's actions should be supervised by the Administrative Court as legal enforcement in administrative law, fulfill the civil rights. The government's act might be different from the previous, and this is an essential point to the Administrative Court to develop their role and authority.

As globalization becomes a world phenomenon, the administrative law also has to shift from the traditional government to modern government. The new paradigm of administrative law highly demands to build modern governance, its reform and facing 
global governance, the shifting paradigm of administrative law is required to challenge the government's reform include organizational, operational and process as well as new approaches of human management (7). This is related to the Administrative Court's role, is to keep the rights of the people and public interest in the balance position. The relations between government, government reform, and administrative court are essential to challenge the globalization.

The role of the Administrative Court is to settle the administrative dispute, but the type of dispute might vary due to the changes of globalization. The fast changing of information technology is to give impact to social-cultural live include the government's actions. In the Article No. 30 / 2014 of Governance Administration regulates the decree of government in electronic type should be made or give, legally binding, and effective from the time received by the applicant when the written decree not being made or give.

The e-government increased rapidly as fast as the development of technology. Many countries using this advantage to make more accessible some applications. E-government is one of the phases to move forward from the conventional to modern government, and also to reduce the use of paper in order to reuse the environment. This e-government has to follow by the regulation and law enforcement, whether administrative, private, and penal law.

In Australia, the judiciary system has been made some changes due to development of information technology, from the beginning of the 1980s, and the government realized that future courts are built on many factors, i.e., management organization, case management, harnessing technology, culture innovation and others related. (8) It showed that governments prepare the structure, substance, and legal culture to face the globalization in proper and managed carefully.

The judiciary system has to follow this globalization starts from the regulations of the procedural process, the judges, the administration of the court system, and related things. We can use the internet to know the progress of cases, the monthly or yearly cases, also the judge's verdict, this is one of the advantages of technology and the impact of globalization. The using of web information of courts are vary widely across Europe, as web organization and information are centralized, while others have a different type. (9) Moreover, it is essential also to expand the judge's view, how to settle dispute reasonably, quickly, precisely and based on law; this will take time as it is not so easy to change all of the above opinions.The principles of Administrative Court might be shifting to modernization, without ignoring the previous one, this becomes a primary needs in this era.

As a comparison, in the Netherland judiciary system, they made a new Judiciary Organization Act and proposed some critical institutional changes. There should be a management board for each court, not include the Supreme Court, also introduce the new financing system, to improve the management skills of managing judges. (10) Tonn. Et .al suggested future of the courts based on crucial role in society either in government, as shown in 5 (five) dimensions missions of Hawaii judiciary, are the judiciary as branch of government, as dispute resolution forum, as public agency, as a subsystem of Legal System, as an institution of a changing society. (11) As we see in Indonesia, it is necessary to consider 5 (five) dimensions might be essential to develop the function and role judiciary body, by making some changes or amendment of related regulations.

The challenges to reform, re-manage the judiciary body in globalization era is to put the law as the highest norm for the nations and society. Moreover, the Administrative Court as a judiciary body has to honor and respect the law in State's society. (12) The steps which had been taken by the Dutch could be used in our judiciary system by considering essential 
points, i.e., the Constitution of 1945, ideology, nations aims, social-economy, etc. The remanage of the judiciary system in Indonesia already started, and it still being in progress to give better service and more comfortable to get access to justice.

In India, they develop the e-court, which is a paperless court, saving money not only for the State but also for the people who could not afford the loss of time, money, and work. (13)This shifting public service in India, it is a sign of progress and prosperity. They have been used the internet for several years to develop the government's services and much other related government's matters.

\section{Conclusion}

The Administrative Court has vital role to supervise government's act, law enforcement in administrative law and protection of the civil rights as well as to empower this role toward modern governance, starting from the new regulations of administrative law and governmental reform The new regulations have aimed to embody the modern court which based on people's needs, fast-moving technology, management of the court, judges, and parties related. To increase the role of Administrative Court, the paradigm shift of administrative law is essential, and there should be an adjustment, harmonized, and synchronized regulations.

\section{References}

[1] Wignjosoebroto S. Ragam-ragam Penelitian Hukum. In: Irianto S and S, editor. Metode Penelitian Hukum Konstelasi dan Refleksi. First Edit. Jakarta; 2011. p. 12141.

[2] Ten Berge G. Towards an equilibrium between citizens ' rights and civic duties about government. Utr Law Rev. 2007;3(2):219-26.

[3] Abdoellah P. Revitalisasi Kewenangan PTUN Gagasan Perluasan Kompetensi Peradilan Tata Usaha Negara. Yogyakarta: Cahaya Atma Pustaka; 2016. 45-47 p.

[4] Mawardi I. Paradigma Baru PTUN Respon Peradilan Administrasi Terhadap Demokratisasi. Yogyakarta: Thafa Media; 2016. 52-54 p.

[5] Manan B. Mewujudkan Peradilan Yang Bersih dan Berwibawa Melalui Good Governance. In: Menegakkan Hukum Suatu Pencarian. Jakarta: Asosiasi Advokat Indonesia; 2009. p. 257-74.

[6] Hasan M. Manifestations of Globalization At Regional and Local Levels the Concept of Globalization and How This Has Impacted on Contemporary Muslim Understanding of Ummah. J Glob Stud. 2011;2(2):145-59.

[7] Yeh J. Globalization, Government Reform and the Paradigm Shift of Administrative Law Globalization, Government Reform and the Paradigm Shift of Administrative Law. 2015;(September).

[8] Foster BR. Towards Leadership: The Emergence Of Contemporary Court Administration In International Journal For Court Administration | February 2013 International Journal For Court Administration | February 2013. Int J Court Adm. 2013;(February):1-12.

[9] Velicogna M. Justice systems and ICT What can be learned from Europe? Utr Law Rev [Internet]. 2007;3(1):129-47. Available from: http://www.utrechtlawreview. org/articles/10. 18352/ulr.41/ 
[10] Langbroek P. Organization Development of the Dutch Judiciary, between Accountability and Judicial Independence. Int J Court Adm [Internet]. 2010;2(2):21-30. Available from: http://www.iacajournal.org/index.php/ijca/article/view/URN:NBN:NL:UI:10-1115887

[11] Tonn B, Stiefel D, Scheb JM, Glennon C, Kumar H. Future of the courts : Fixed, flexible, and improvisational frameworks. Futures [Internet]. 2012;44(9):802-11. Available from: http://dx.doi.org/10.1016/j.futures.2012.07.005

[12] Supandi. Lembaga Peradilan, Kualitas Profesionalisme Dalam Proses Pembaruan dan Konsekuensi Terhadap Pencederaan Etika Profesi. In: Kapita Selekta Hukum Tata Usaha Negara. Bandung: Alumni; 2016. p. 223.

[13] Prakash SBN. E Judiciary : A Step towards Modernization in Indian Legal System. J Educ Soc Policy. 2014;1(1):111-24. 